\title{
Retraction
}

\section{Retracted: On Multistep Iterative Scheme for Approximating the Common Fixed Points of Contractive-Like Operators}

\author{
International Journal of Mathematics and Mathematical Sciences \\ Received 21 December 2011; Accepted 21 December 2011 \\ Copyright ( $) 2011$ International Journal of Mathematics and Mathematical Sciences. This is an open access article distributed \\ under the Creative Commons Attribution License, which permits unrestricted use, distribution, and reproduction in any medium, \\ provided the original work is properly cited.
}

This article has been retracted as it is essentially identical in technical content with a previously published paper in Fasciculi Mathematici. The earlier publication is "THE CONVERGENCE OF JUNGCK-TYPE ITERATIVE SCHEMES FOR GENERALIZED CONTRACTIVE-LIKE OPERATORS," Johnson O. Olaleru and Hudson Akewe, nr. 45 (2010) [1].

\section{References}

[1] J. O. Olaleru and H. Akewe, "On multistep iterative scheme for approximating the common fixed points of contractive-like operators," International Journal of Mathematics and Mathematical Sciences, vol. 2010, Article ID 530964, 11 pages, 2010. 